\title{
Leprosy in Malaya
}

\author{
DR. B. L. MALHOTRA, M.B.H.S. \\ Senior WHO Officer I 954-1957 Medical Superintendent, \\ Sungei Buloh Leprosarium \\ GEOGRAPHICAL POSITION
}

The Federation of Malaya covers the southern portion of the Kra Peninsula in South East Asia which protrudes from the Asian land mass between India and China. The southern tip of the Peninsula is joined by a causeway to the Island State of Singapore.

The country covers 5 , , ooo square miles ( $156,000 \mathrm{sq} . \mathrm{km}$.) the settled and cultivated arca lic along the two coastal strips and four-fifths is a jungle. 'The rubber, palm oil estates and tin are the mainstay of the country's economy. 'The rainfall ranges from 67 to 232 inches (I 75 to $598 \mathrm{~cm}$.) being variable in different parts of the country. Federation comprises nine Princely States and two Settlements of Penang and Malacca. After the termination of the World War II, the country was in the grip of the Communist trouble and the State of Emergency lasted for nearly twelve years.

'The country was given Independence in August I 957. Population stands at 6,279,00o (census I 957) but the corrected population on Ist January, I 962, was 7,200,000 comprising of different races, Malayasians, Chinese and Indians in the ratio of $49.8,47.2$ and I I 3 per cent respectively, the remaining I 8 per cent being others. Chinese have higher expectancy of life, next Indians and lastly the Malaysians. Overcrowding is the common feature of the Chinese households which could very well account for the higher incidence of leprosy. Expenditure on Health and Social Services has increased from 8 to $9 \frac{1}{2}$ per cent in the years I960 and 196 I. On cducation the expenditure comes to about $19 \frac{1}{2}$ per cent of the total revenue. This country has the highest per capita income amongst the many of the Asian countries, likewise the country enjoys the highest standard of living.

The main purpose behind giving the description of the country is to dissipate wrong notions from the minds of the readers. Some still live in a world of their own while travelling in other countries and while having the privilege of meeting foreigners, they did not know where Malaya was and everyone without exception indentified Singapore as Malaya. Very recently, I had the honour to meet a distinguished Scientist from India who had the impression that Kuala Lumpur is known because of Sungei Buloh.

It is due to the present Prime Minister that a small country has been brought into the forefront whose voice is heard with respect.

At the outset while giving the readers the actual position of leprosy in the country, it must be made clear that the data was derived from later 
experience when the writer served on a survey on school children in the Island of Penang. 'Ihus all the data that is mentioned in the brief paper are the ones which have been collected in the last four months since I took up the post of Medical Superintendent, Sungei Buloh Leprosarium. So far the main emphasis has been on the institutions and now the Government is contemplating the organizing of a National Leprosy Control Programme and the beginning has been made by the arrival of a WHO Consultant who will be submitting a plan of operations. It may be possible to start a programme in the next two to three years.

The various activities of the Leprosy Department in the Federation will be discussed under the following headings:

I. Institutions;

4. Legislation;

2. Ficld Work;

5. Research;

3. Clinics and Treatment;

6. Malayan Leprosy Relief Association (MaLRA).

INSTITUTIONS

There are thrce leprosaria, Pulau Jerejak in the North, Sungei Buloh in the Centre and Tampoi in the extreme South.

S UNGEI B ULOH

This Institution covers an area of 600 acres (24,689 sq. decam.) and situated in a beautiful valley about 9 miles from the fringe of the capital city of Kuala Lumpur. Originally the present site was home for the aged, when in 1930 leprosy patients from different parts of the Federation were brought here and thus the Leprosarium came into existence. Since then there had been I 5 superintendents in succession. Each Superintendent had left a good record of progress and the Institution had been expanding gradually to the present day Leprosarium with the unrivalled multiactivities apart from treatment. Two names are worth mentioning, DR. RYRIE who was Superintendent during the Japanese Occupation had very difficult times and was put in the Concentration Camp, leaving DRS. ABRAHAM and CHELAH who had to bear the brunt of the Administration, the former died of heart failure due to hard work. Since the end of the Occupation, the Institution has made tremendous improvements.

The Leprosarium has 2,500 inmates who are housed in single, double and dormitories numbering about 500 with modern plumbing and conservancy arrangements. The affairs of the inmates are managed by a Council which is a registered body with the Registrar of the Societies. The Council consists of I I members, four of them being nominated by the Superintendent. The main source of income is a monthly grant of $\$ 2,500$ from the Malayan Leprosy Relief Association and revenue collections from the taxes on the shops, etc., there being 22 shops or stalls. The main occupation of the inmates being - goat, poultry and pig rearing, vegetable and fruit farming which brings a substantial income for them. The Council maintains a Community Centre, Stadium, Cinema and Theatre. Apart from these non-denominational activities they have different places of worship, three churches, one Mosque, a Temple and Buddhist Shrine. 
'The latter was built by a discharged patient at the cost of $\$ 35$, ooo and the inmates had further spent a sum of $\$_{15}$,, 000 to equip it.

On the medical side, the admission is restricted to the lepromatous and for those cases who require specialized treatment. All cases admitted are $\mathrm{X}$-rayed and photographed.

'The Leprosarium is divided into three sections: West, Central and East, the West forms the hub of the Institution. This consists of administrative offices, laboratories, research wards, X-rays, Physiotherapy and Occupational 'Therapy departments, and is well equipped with an Artificial Limb Centre. Apart from providing artificial limbs to the inmates, it caters to the needs of all the leprosy patients of the Federation.

In addition, there is a well-planned and equipped Babies' Home under the supervision of the Nursing Staff. 'The babies immediately on birth are separated and transferred to the Babies' Home, who after the age of six months are either adopted by the relatives or sent to the Social Welfare Homes in the country. At the time of writing this article, there are 22 babies in the Home.

The Hospital wards are divided into two sections, one section consisting of ten wards is exclusively for incurable patients, another section comprising of 19 wards is reserved for cases who require hospital treatment.

The other sections, East and Central are completely independent treatment units under the charge of Medical Officers. The Ophthalmic and Dental Clinics are attached to the East Section and are attended by the visiting Dental and Ophthalmic Surgeons.

The Leprosarium maintains a block for prisoners who are infectious and sent for detention and treatment. The Government has built a block of I 20 beds for mental patients at a cost of \$igo,ooo. An Occupational Therapist specialized in training mental patients has been appointed.

The Institution has built an up-to-date Nursing School at a cost of $\$ 47,000$ for the training of Assistant Nurses and other paramedical staff.

Any description of the Leprosarium will not be complete if a very important activity is not mentioned. There is an up-to-date well equipped school named after DR. TRAVERS who was the first visiting Medical Officer who started teaching before the World War II. Since then the beginning has grown to a full scale school imparting education up to Cambridge School Certificates and London Chambers of Commerce. The present enrolment is 250, the children are being drawn from all over the Federation. The school can boast of having turned out students who are employed in the Commercial Firms, Government Departments and factories. Apart from education, there are extra-mural activities.

The annual expenditure of Sungei Buloh Leprosarium amounts to $\$ 2,000,000$ per annum (about $£ 250,000$ ).

PULA U JEREJAK

The second Institution is situated at Pulau Jerejak, an off-shore island about half a mile from the main Island of Penang. In I850, the leprosy 
patients were living in a lane in Penang at the charity of a wealthy Chinese and the lane became known to the Chinese as 'Tha ko hung', 'LEPER LANE'. In 1870, says the Chronicle, the Infectious 1)iscase Ordinance was passed and the same year Pulau Jercjak became a 'Leper Asylum' and patients were transferred to Pulau Jerejak. 'This Asylum was originally meant for the Straits Settlements, but later on other Leprosaria came into existence.

TAMPOI LEPROSARIUM

This is situated in the extreme South and was founded in the year I929.

In addition to the above three I.eprosaria there is a miniature Leprosarium in the form of a ward of 67 beds attached to Kota Bharu Hospital on the East Coast.

T A B I. F: I

Shows the Statistics of the Four Leprosaria:

\begin{tabular}{|c|c|c|c|c|c|c|}
\hline \multirow[b]{2}{*}{ Name of Institution } & \multirow[t]{2}{*}{ Total } & \multicolumn{2}{|c|}{ Sexes } & \multirow[b]{2}{*}{ Lepromatous } & \multicolumn{2}{|c|}{ Type } \\
\hline & & $M$ & $F$ & & Tuberculoid & Unclassified \\
\hline Sungei Buloh & 2,485 & $\mathrm{I}, 809$ & 676 & $75^{\circ}$ & 1.735 & - \\
\hline Pulau Jerejak & 454 & 380 & 74 & 317 & 137 & - \\
\hline 'Tampoi & 422 & 301 & 121 & 307 & 103 & 12 \\
\hline Kota Bharu Ward & 67 & 45 & 22 & $4^{I}$ & 26 & - \\
\hline Total & 3,428 & 2,535 & 893 & I,4 I 5 & 2,001 & 12 \\
\hline
\end{tabular}

S T A F F

The country as a whole is short of doctors and the leprosaria are effected likewise. Apart from the shortage of doctors, the doctors are reluctant to act as medical officers of the institutions. Table No. III shows the present position. However, there is no cause for complacency as the Government is making every effort to recruit medical officers as a temporary arrangement till the medical faculty starts turning out medical graduates.

\section{FIELD WORK}

As I have already mentioned, no serious attempt had been made to survey the country but when I was in Penang Island I carried out a pilot survey of schools. I spent six months in surveying 39 schools and examined 4,905 children (boys 3,047 and girls $1,85^{8}$ ) out of 5,040 .

The results have been disappointing and proved a time-consuming factor when only five cases (four boys and one girl) were picked up. On the other hand 20 school children who attended the Skin Clinic complaining of skin diseases, were found to be suffering from leprosy. 
TABLE II

Showing the Births, Deaths, Admissions, Re-Admissions and Discharges during the last Five Years

\begin{tabular}{|c|c|c|c|c|c|c|c|c|c|c|c|c|c|c|c|c|c|c|c|c|c|c|c|c|c|}
\hline \multirow[b]{2}{*}{ Tables } & \multicolumn{5}{|c|}{ Births } & \multicolumn{5}{|c|}{ Deaths } & \multicolumn{5}{|c|}{ Admissions } & \multicolumn{5}{|c|}{$R e-A d m i s s i o n s$} & \multicolumn{5}{|c|}{ Discharges } \\
\hline & 1958 & 5.9 & $6 o$ & $6 I$ & 62 & 1958 & 59 & $6 o$ & $6 I$ & 62 & 1958 & 59 & 60 & $6 I$ & 62 & 1958 & 59 & 60 & $6 I$ & 62 & 1058 & 52 & 60 & $6 I$ & 62 \\
\hline $\begin{array}{l}\text { Sungei Buloh } \\
\text { Leprosarium }\end{array}$ & $3^{8}$ & I 8 & 32 & 30 & 33 & 40 & 39 & 42 & 44 & 45 & $3^{\text {II }}$ & 340 & $33^{2}$ & 3 Io & 309 & I 86 & I 92 & 212 & I9I & $2 ! 4$ & 396 & 426 & $38 \overline{5}$ & $42 \mathrm{I}$ & $5^{1} 3$ \\
\hline Pulau Jerjak & I I & I I & I I & 6 & 7 & I 7 & 12 & I I & 8 & 9 & I9 & 33 & 30 & 30 & 33 & 2 & 6 & 4 & 9 & 6 & 33 & 30 & $2 \mathrm{I}$ & I 9 & 25 \\
\hline Tampoi & 7 & 6 & 3 & $\mathbf{I}$ & I & 8 & 2 & 4 & 5 & I 8 & 12 & I 6 & 23 & 39 & 47 & 4 & IO & 9 & 13 & 17 & 14 & II & 9 & $\mathrm{IO}$ & 9 \\
\hline Total & 56 & 35 & 46 & 37 & $4^{I}$ & $6 \overline{5}$ & 53 & 57 & 57 & 72 & 342 & 389 & 405 & 379 & $3^{89}$ & I 88 & 208 & 225 & 2 I 3 & 237 & $44^{8}$ & 467 & 41.5 & 450 & 457 \\
\hline
\end{tabular}


TA BI.E I I I

Showing the Staff Position

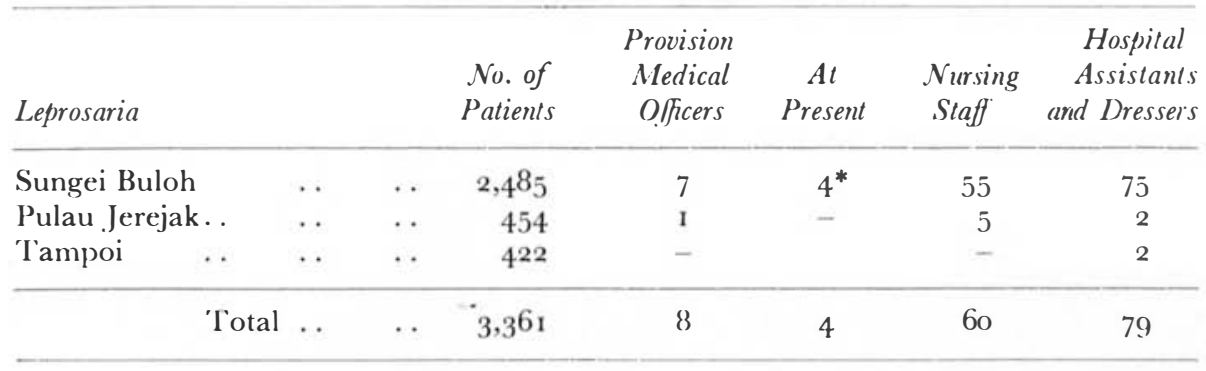

* Including Medical Superintendent.

Medical () Micer I for 840 cases and Nursing Staff a for $5^{6}$ cases.

I think that in a country like this where there is a shortage of medical officers, extensive or intensive surveys would not be justified, but the following up of known cases and their contacts by medical or paramedical personnel would be the best solution.

\section{NICS AND TREATMENT}

The routine treatment consists of the use of sulphones with Ciba- I9o6 and for the treatment of lepra reaction, apart from using the conventional drugs, a good deal of steroids are used. Surgical treatment is carried out for the deformities of the hands and feet.

Out-patient treatment is available all over the country either through the mobile unit or at different hospitals. Apart from the four leprosaria the treatment is provided at 33 centres. Of these 33, ten clinics are covered by the mobile unit which is under the supervision of the Malayan Leprosy Relief Association in the Eastern Coast. MaLRA spends about \$30,0oo (about $£ 3,000)$ every year for relief and allowances to the patients to attend for the treatment. The attendance of these ten clinics is almost Ioo per cent whether due to treatment or because the patients are attracted by the transport allowances, and it is very difficult to say which is correct.

\section{LEG IS L A T I O N}

The Leper Ordinance was enforced in the year 1926 and is outmoded in the light of the present day approach to the problems of leprosy. By law every patient irrespective of type is required to be segregated either by his own efforts under the supervision of the health authorities or in the Leprosaria. The law provides that every case should be discharged by the Ministry of Health on the recommendations of the Medical Superintendant. Though the ordinance should be strictly applied, it is becoming more or less a dead letter. Efforts are being made to repeal the outmoded act. 
TABLE IV

Showing Treatment of Cases as Out-Patients in the Federation

\begin{tabular}{|c|c|c|c|c|c|c|c|c|}
\hline \multirow{2}{*}{ State } & \multirow{2}{*}{\multicolumn{2}{|c|}{ Location of the Clinic }} & \multirow{2}{*}{ Total } & \multicolumn{2}{|c|}{ Sex } & \multicolumn{3}{|c|}{ Types of classification } \\
\hline & & & & $M$ & $F$ & $L$ & $T L$ & classified \\
\hline \multirow[t]{4}{*}{ Kedah } & ( $\mathrm{I})$ & Kulim & 27 & 22 & 5 & I & 26 & - \\
\hline & (2) & Sungei Patani & I & & - & I & - & - \\
\hline & (3) & Alor Star & 62 & 48 & I 4 & - & - & 62 \\
\hline & (4) & Baling & 2 & 2 & - & - & 2 & - \\
\hline \multirow[t]{3}{*}{ Johore } & ( $\mathrm{I})$ & Tangkak & 3 & 3 & - & I & 2 & - \\
\hline & (2) & Batu Pahat & 14 & 14 & - & 3 & I I & - \\
\hline & (3) & Muar & 46 & $4^{\circ}$ & 6 & - & 46 & - \\
\hline \multirow[t]{3}{*}{ Penang } & ( 1 ) & General Hospital & 488 & 354 & I 34 & I 94 & 269 & 25 \\
\hline & (2) & Bukit Merterjam & 19 & 15 & 4 & Io & 9 & - \\
\hline & (3) & Sungei Bakap & 18 & 17 & I & 17 & I & - \\
\hline Pahang & (I) & Raub & 4 & 3 & 1 & 3 & $\mathbf{I}$ & - \\
\hline \multirow[t]{4}{*}{ Perak } & $(\mathrm{I})$ & Taiping & 9 & 6 & 3 & 8 & I & -- \\
\hline & (2) & I.umut & 2 & 2 & - & - & - & 2 \\
\hline & (3) & Tapah & 2 & 2 & - & - & 2 & - \\
\hline & (4) & Parit Buntar & 4 & 4 & - & - & - & 4 \\
\hline \multirow{2}{*}{ 'Trengganu } & $(1)$ & Dungun & 2 & - & 2 & 2 & - & - \\
\hline & $*(2)$ & Besut & $2 \mathrm{I}$ & 15 & 6 & 6 & 15 & - \\
\hline \multirow[t]{3}{*}{ Selangor } & $(\mathbf{I})$ & Kuala Kubu Bharu & 2 & - & 2 & I & I & - \\
\hline & (2) & Kuala Lumpur & I 06 & 85 & 21 & IO & 96 & - \\
\hline & (3) & $\begin{array}{l}\text { Sungei Buloh Clinic } \\
\text { out-patient }\end{array}$ & $4^{6}$ & $3 I$ & 15 & 3 & 27 & I 6 \\
\hline Malacca & (I) & Malacca & 15 & 12 & 3 & 2 & I 3 & - \\
\hline \multirow{10}{*}{ Kelantan } & $*(\mathrm{I})$ & Kuala Krai & 12 & 7 & 5 & 6 & 6 & - \\
\hline & (2) & Kota Bharu & 284 & 211 & 73 & 98 & I 86 & - \\
\hline & *(3) & Pasir Nas & I 33 & 83 & $5^{\circ}$ & 30 & Io3 & - \\
\hline & $*(4)$ & 'Tumpat & 67 & $3^{8}$ & 29 & 23 & 44 & - \\
\hline & $*(5)$ & Tanah Merah & 33 & 21 & 12 & I I & 22 & - \\
\hline & *(6) & Machang & 20 & 14 & 6 & 4 & I 6 & - \\
\hline & *(7) & Pasir Puteh & 40 & 25 & 15 & 8 & $3^{2}$ & - \\
\hline & *(8) & Bachok & $3^{8}$ & 23 & 15 & I6 & 22 & - \\
\hline & *(9) & Dabong & 3 & 3 & - & - & 3 & - \\
\hline & ( 10$)$ & Kota Bharu Hospital & 67 & 45 & 22 & $4^{1}$ & 26 & - \\
\hline Negeri & $(\mathrm{I})$ & Kuala Pilah & 3 & 2 & I & - & - & 3 \\
\hline \multirow[t]{2}{*}{ Sembilan } & (2) & Port Dickson & 5 & 2 & 3 & - & - & 5 \\
\hline & 33 & & I , 598 & $\mathrm{I}, \mathrm{I} 5^{\mathrm{O}}$ & $44^{8}$ & 499 & I,o99 & I I 7 \\
\hline
\end{tabular}

* Clinics covered by Mobile Units. 
TABI.F, V

Showing Incidence Statewise in the Federation

\begin{tabular}{|c|c|c|c|c|c|}
\hline & State & $\begin{array}{c}\text { Area } \\
\text { in Sq. Miles }\end{array}$ & $\begin{array}{l}\text { Population } \\
\text { mid-196o }\end{array}$ & $\begin{array}{c}\text { Total Table } \\
\text { Ciases }\end{array}$ & $\begin{array}{c}\text { Incidence } \\
\text { Per }-\mathrm{I}, \mathrm{OOO}\end{array}$ \\
\hline (I) & Selangor & 3,167 & I, I I 9,673 & 823 & 0.73 \\
\hline (2) & Perak & 7,980 & I , 344,4 I I & 662 & 0.49 \\
\hline (3) & Pahang & I 3,873 & 343,015 & I 29 & 0.37 \\
\hline (4) & Penang & 398 & 623,949 & 1,005 & I. 6 \\
\hline$(5)$ & Perlis & 310 & 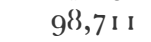 & I9 & .19 \\
\hline (6) & Johore & $7,33^{\circ}$ & I ,026, I O I & $54 I$ & $0.5^{2}$ \\
\hline (7) & Kelantan & $5,75^{\circ}$ & 533,001 & $73^{8}$ & I. 2 \\
\hline (8) & 'Trengganu & 5,027 & 306,942 & 46 &. $\mathrm{I}$ \\
\hline (9) & Negeri Sembilan & 21,565 & 407,809 & 185 & .45 \\
\hline ( $\mathrm{I}(\mathrm{O})$ & Malacca & 640 & $323,34^{8}$ & I 33 & $0.4 \mathrm{I}$ \\
\hline \multirow[t]{4}{*}{ (II) } & Kedah & 3,660 & 761,999 & 312 & .49 \\
\hline & ()ther Neighbouring & 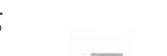 & $\pi$ & 378 & \\
\hline & & & & & \\
\hline & Total & 69,700 & $6,888,959$ & $4,97 \mathrm{I}$ & .7 \\
\hline
\end{tabular}

Note: 75 per cent of the cases are Chinese.

\section{RESEARGH UNIT}

'The Unit was commenced in March 1957 and it has continuously expanded.

The medical Research Council of Great Britain is maintaining a Research Officer whilst the Government is supplying all the necessary equipment and finances. The main lines of research are in the trial of new drugs and control of leprosy by BCG. The latter was started in I 959 and the project is still under study.

MALAYAN LEPROSY RELIEF ASSOCIATION

The Malayan Leprosy Relief Association was established in the year I 959 under the patronage of Her Majesty The Raja Permaisuri Agong. The Central Branch has three branches at other States, the Medical Superintendent, Sungei Buloh Leprosarium, Sungei Buloh, acts as Honorary Medical Adviser. The main income of the MaLRA is derived from the Lotteries Board. This Association gives financial relief to patients here and there and distributes supplies of food stuffs, and seeks employment for discharged cases.

MaIRA has established a wood and metal workshop at the cost of $\$ 60,000$, the Babies' Home (as mentioned above) $\$ 40,000$ and a poultry farm which has 7,300 birds and produces about I, ooo eggs a day. MaLRA has acquired about I, ooo acres (about 40,468 sq. decam.) of land out of which 200 acres (about 800 sq. decam.) has been brought under oil palm cultivation and another 200 is in the process of developing and planting with rubber and 40 (about $\mathrm{I} 6 \mathrm{o}$ sq. decam.) for fruit farming. 
'The entire labour force is drawn from the Sungei Buloh I.cprosarium. It is hoped that the remaining land will be developed and made use of with the hope of good return after some years and to utilise the income towards relief and rchabilitation.

\section{S U M M A R Y}

I. A good opportunity exists in Malaya for any national leprosy control. Institutional care is of the best that is available and it is felt that it has reached the saturation stage. Ficld work has not been established.

2. Thus leprosy has remained more of a medical problem than health.

3. Owing to the absence of any health education on leprosy, there exists an extensive gulf between the patient and the public thus creating problems of rehabilitation. 'The main rehabilitation performed by the Government is on the employment of a few discharged patients in leprosy institutions. 'Though the objective of the Malayan I.eprosy Relief Association is to rehabilitate, time is needed, and it may be years before the discharged patients can expect any benefits.

4. The apathy of medical officers towards serving in the Ieprosaria is evidenced by the fact that since the establishment of the Icprosaria, barring 2-3 local officers, all have been outsiders on contract or otherwise. 'The World Health Organisation has offered a fellowship for six months and there has been no applicant from the medical officers in the Federation.

'The writer does not claim any originality, but the above are the results of his observations ever since he assumed charge as Medical Superintendent, Sungei Buloh I eprosarium.

I express my grateful thanks to DATO DR. MOHAMED DiN, Director of Medical Services, Federation of Malaysia, Kuala Lumpur, for permitting me to publish the above article and mR. R. DevaraJ, Clerk, Sungei Buloh Leprosarium for collecting and tabulating the statistics and finally mRs. м. samson, 'Typist, Sungci Buloh Leprosarium who was kind enough to do the typing for me.

NOTE:

I. Since writing this report, Malaya has become Malaysia by the incorporation of Singapore, Sarawak and Borneo 'Territories.

2. The WHO Consultant has left after completing the six months assignment in Malaya and submitted a report which will be discussed in due course. 